\title{
Nano-Nesnelerin İnternetinin Gelecekteki Uygulamalarına Yönelik Bir Yol Haritası
}

\author{
Emre Şahin $^{1 *}$, Orhan Dağdeviren², Mustafa Alper Akkaş ${ }^{3}$ \\ 1* Pamukkale Üniversitesi, İktisadi ve İdari Bilimler Fakültesi, Yönetim Bilişim Sistemleri Bölümü, Denizli, Türkiye, (ORCID: 0000-0002-4276-3300), \\ emresahin@pau.edu.tr \\ ${ }^{2}$ Ege Üniversitesi, Uluslararası Bilgisayar Enstitüsü, İzmir, Türkiye (ORCID: 0000-0001-8789-5086), orhan.dagdeviren@ ege.edu.tr \\ ${ }^{3}$ Bolu Abant İzzet Baysal Üniversitesi, Mühendislik Fakültesi, Bilgisayar Mühendisliği Bölümü, Bolu, Türkiye (ORCID: 0000-0003-0185-0464), \\ alperakkas@ibu.edu.tr
}

(3rd International Congress on Human-Computer Interaction, Optimization and Robotic Applications June 11-13, 2021)

(DOI: 10.31590/ejosat.951879)

ATIF/REFERENCE: Şahin, E., Dağdeviren, O. \& Akkaş, M. A. (2021). Nano-Nesnelerin İnternetinin Gelecekteki Uygulamalarına Yönelik Bir Yol Haritası. Avrupa Bilim ve Teknoloji Dergisi, (26), 174-179.

\section{$\ddot{O} \mathbf{z}$}

Boyutları 1 ile $100 \mathrm{~nm}$ arasında değişen belirli bir amaca hizmet edecek yapıların geliştirilmesi ve bu yapıların atomik ya da moleküler düzeydeki kontrolü üzerine yapılan bilim ve mühendislik çalışmalarına nanoteknoloji denir. Nanoteknoloji, küçük boyutlardaki veri depolama, algılama, basit hesaplama ve önceden tanımlı komutları yürütme gibi temel görevleri yerine getiren nano ölçekteki bileşenlerin geliştirilmesini sağlamıştır. Nano-aygıtların geliştirilme stratejilerine yönelik farklı yaklaşımlar olmakla birlikte bu konu güncel araştırma alanlarından birisidir. Başlarda tekil olarak ön tanımlı basit işlemlerin gerçekleştirilmesi amacıyla geliştirilen bu pasif cihazlar yüksek hesaplama gücü gerektiren karmaşık işlemler karşısında yetersiz kalmış, bunun sonucu olarak da nano ölçekteki cihazların belli bir amaç doğrultusunda birlikte hareket etmesini sağlayacak aktif bir nano-ă̆ yapısı ihtiyacı ortaya çıkmıştır. Diğer yandan günümüzde hemen hemen tüm teknoloji ürünlerinin haberleşme protokolleri vasitasıyla birbirleriyle iletişim kurabilmeleri beklenmektedir. Bu doğrultuda, nano ölçekteki cihazların mevcut haberleşme teknolojileri vasıtasıyla mikro ya da makro ölçekteki cihazlarla iletişim kurabilmesi ya da bu cihazlar tarafindan kontrol edilebilmesi düşüncesi Nano-Nesnelerin İnterneti - Internet of Nano-Things (IoNT) olarak adlandırılan yeni bir ağ paradigmasının doğmasına neden olmuştur. IoNT, hava kirliliği tespit çalışmalarından genetik mühendisliğine, tarım faaliyetlerinden yüksek hızda veri aktarımına kadar birçok farklı alan için yenilikçi uygulamalar sunmaktadır. Son yıllardaki teknolojik gelişmelerle birlikte, önümüzdeki birkaç yıl içerisinde IoNT'nin hayatımızın hemen hemen her alanında karşımıza çıkması beklenmektedir. Ancak IoNT sahip olduğu birçok avantajın yanı sıra, çözülmesi gereken bazı problemleri de beraberinde getirmektedir. Bu problemlerin başında da nano-aygıtların, sahip olduğu özellikler nedeniyle nano-ağ yapılarına özgü haberleşme protokollerine ihtiyaç duyması gelmektedir. Bu bağlamda nano-aygitlar, nano-ağlar ve nano-haberleşme teknolojileri araştırmacılar için oldukça güncel ve özgün araştırma konuları sunmaktadır.

Anahtar Kelimeler: Nanoteknoloji, Nano-aygit, Nano-Nesnelerin İnterneti.

\section{A Roadmap to Future Applications for Internet of Nano-Things}

\begin{abstract}
Nanotechnology is the scientific and engineering studies on the development of structures that will serve a specific purpose with sizes ranging from 1 to $100 \mathrm{~nm}$ and the control of these structures at the atomic or molecular level. Nanotechnology has enabled the development of nanoscale components that perform basic tasks such as small-sized data storage, sensing, basic computation, and executing predefined commands. Although there are various approaches to the development of nano-devices, this subject is one of the current research areas. Originally developed to perform simple predefined tasks alone, these passive devices fell short for complex
\end{abstract}

* Sorumlu Yazar: emresahin@pau.edu.tr 
operations requiring high computing capacity. As a result, it has emerged that there is a need for an active nano-network structure that would allow nano-scale devices to act together for a specific purpose. On the other hand, nowadays, it is expected that almost all technology products will be able to communicate with each other via communication protocols. The idea that nano-scale devices can communicate with micro or macro-scale devices via existing communication technologies or can be controlled by these devices has led to the emergence of a new network paradigm called the Internet of Nano-Things (IoNT). IoNT offers innovative applications for many different fields, from air pollution detection systems to genetic engineering or agricultural activities to high-speed data transfer. With the technological developments in recent years, it is expected that IoNT will appear in almost every aspect of our lives in the next few years. However, in addition to its advantages, IoNT also brings some problems to be solved. The most important of these problems is that nano-devices require communication protocols specific to nano-network structures due to their properties. In this context, nano-devices, nano-networks, and nano-communication technologies offer novel and original research topics for researchers.

Keywords: Nanotechnology, Nano-device, Internet of Nano-Things.

\section{Giriş}

Nanoteknoloji fikri ilk olarak 1965 yılı Nobel Ödülü sahibi Richard Feynman tarafindan ortaya atılmıştır (Akyildiz ve ark., 2008). Feynman, insanların gelecekte boyutları giderek küçülen, bununla beraber kapasiteleri ise giderek artan cihazlar geliştireceğini belirtmiştir. Öte yandan, nanoteknoloji basitçe nano ölçekte yürütülen bilim, mühendislik ve teknoloji çalışmaları olarak tanımlanabilir. Daha öncesinde de yapılan bazı çalışmalar olmakla beraber, nanoteknoloji için dönüm noktası 2000'li yılların başları olmuştur. Nanoteknolojinin en temel fonksiyonel birimi, yalnızca basit hesaplama ve iletişim kapasitesine sahip, boyutları 1 ile $100 \mathrm{~nm}$ arasında değişen nanoaygıtlardır. Nano-aygıtların, sahip oldukları sınırlı kaynaklardan dolayı tek başlarına karmaşık işlemleri yerine getirmeleri mümkün değildir. Bu doğrultuda nano-aygıtlar tek bir cihazın sahip olduğu yeteneklerin ötesindeki işleri yerine getirebilmek için merkezi ya da dağıtık yapıda bir araya gelerek nano-ağları oluştururlar. Farklı boyut ve kapasitedeki nano-aygıtların internet aracılığılla birbirine bağlanmasıyla IoNT adı verilen yeni jenerasyon bir haberleşme standardı ortaya çıkmıştır. Yapılan çalışmalarda genellikle biyo-medikal ve sağlık uygulamalarının üzerinde durulmuş olsa da IoNT aslında tarım, üretim, gıda, tüketici elektroniği, otomotiv ve savunma sanayi gibi daha birçok sektör için devrim niteliğinde yenilikler sunmaktadır. Diğer çalışmalardan farklı olarak bu çalışma kapsamında 21. yüzyılın en fazla umut vadeden ve her geçen gün aldığı yatırım miktarı artan IoNT'nin mevcut uygulamalarının yanı sira gelecekte var olması muhtemel potansiyel uygulama alanları da tüm yönleriyle ele alınmıştır. Dahası bahsi geçen uygulamalar, anlaşılırlığı arttırmak için çeşitli görsellerle desteklenmiştir. Diğer yandan nano-aygıtların sahip olduğu boyut ve sınırlı kapasite gibi özelliklerinden dolayı nano-ağ uygulamalarında mevcut ağ teknolojileri kullanılamamaktadır. $\mathrm{Bu}$ durum da beraberinde çözülmesi gereken yeni problemleri getirmektedir. Yüksek hesaplama kapasitesine sahip nano-aygıtların nasıl geliştirileceği, nanoaygıtların birbirleri arasında nasıl iletişim kuracağı gibi problemler bu çalışmanın ana konusunu oluşturmamakla birlikte çalışmanın devam eden bölümlerinde bu konulara da kısaca yer verilmiştir.

Çalışma kapsamında, nanoteknoloji ve IoNT kavramının ortaya çıkış süreci, kısa tarihçesi, son yıllardaki en büyük yatırımcıları ve mevcut pazar payı Bölüm 2'de, IoNT'nin mevcut ve potansiyel uygulamaları, doğrudan ya da dolaylı olarak etkilediği sektörler ve adı geçen uygulamaların sağladığ ya da sağlayacağı kazanımlar Bölüm 3 'te verilmiştir. Son bölümde ise IoNT teknolojileri ile ilgili geleceğe dair beklentiler ve tahminlerin yanı sıra, bu teknolojilerin beraberinde getirdiği aşılması gereken problemler irdelenmiştir.

\section{Nano-Nesnelerin İnterneti (IoNT)}

Son çeyrek asırdır Nesnelerin İnterneti - Internet of Things (IoT) kavramı modern kablosuz haberleşme dünyasında büyük bir popülarite kazanmış ve yeni bir devrim olarak kabul edilmiştir. IoT kavramının ortaya çıkmasıyla birlikte, tek başlarına karmaşık süreçleri ve işlemleri yerine getirebilen gelişmiş cihazlara olan ilgi, belli bir görevi yerine getirmek için çevresindeki diğer cihazlarla ortak bir şekilde hareket etmesi gereken basit cihazların bir araya gelerek oluşturduğu ağ teknolojilerine kaymıştır. Bilgisayar bilimlerinde yaşanan gelişmelerle eş zamanlı olarak fizik, kimya ve malzeme bilimi gibi diğer bilim dallarında meydana gelen gelişmeler, bilgisayar bilimlerindeki araştırma konularını da etkilemiştir. Araştırmacılar tarafından karbon nano tüplerin bulunmasıyla birlikte araştırmacıların ilgisi nano ölçekteki yeni materyallerin geliştirilmesi, atomik ya da moleküler ölçekteki maddelerin direkt kontrolü gibi konulara kaymış ve yalnızca bir kavram olmanın dışında bir araştırma ve bilim dalı olarak nanoteknoloji hayatımıza girmiştir. Nanoteknoloji, yer bilimi, organik kimya, moleküler biyoloji, yarı iletkenler fiziği ve bilgisayar bilimleri gibi birçok disiplini içine alan bir bilim dalı olduğu için son yıllarda hem ülkeler hem de firmalar bu alanda önemli yatırımlar ve çalışmalar yapmaktadır.

Nanoteknolojiyi bu kadar güçlü yapan etmenlerden biri ise nano-aygıtlardır. Bir nano-aygıt algılama ve yürütme gibi temel görevleri yerine getirebilmek amacıyla bir araya getirilmiş nanoparçacıklardan meydana gelen temel fonksiyonel birim olarak tanımlanabilir. Nano-aygıtlar arasındaki etkin iş birliği ve koordinasyon, bu aygıtların farklı işleyiş ve karmaşıklığa sahip birçok uygulamada kullanılabilmesine olanak sağlamaktadır. Kısacası mevcut haberleşme teknolojileri ve yüksek hızlı internet ağlarından yola çıkılarak bu nano-aygıtların birbiriyle iletişim kurabilmeleri fikri IoNT olarak adlandırılan yeni bir kavramın ortaya çıkmasına neden olmuştur. IoNT, Fuat Akyildiz ve Joseph Miquel Jornet tarafindan önerilen bir kavramdır (Akyildiz ve Jornet, 2010). Akyildiz ve Jornet IoNT'yi nano ölçekli aygıtlar arasında modern haberleşme teknolojilerini kullanarak oluşturulan yeni bir ăg yaklaşımı olarak tanımlamışlardır.

Cisco, Huawei, IBM, Intel ve Microsoft başta olmak üzere dünya genelinde birçok firma IoNT'ye önemli yatırımlar yapmaktadır. Yapılan araştırmalar göstermektedir ki, bu yatırımlar doğrultusunda, 2019 yılında yaklaşık 5,3 milyar dolar olan IoNT pazar değeri 2020'de 6,15 milyar dolara yükselmiştir. Dahası 2026 yılında bu sayının 16,8 milyar doları geçmesi beklenmektedir. Benzer şekilde IoNT'nin en temel bileşeni olan nano-duyargaların ise 2019 yılında 432 milyon dolar olan pazar değerinin 2020 yılında yaklaşık olarak 442 milyon dolara kadar yükseldiği ve bu sayının 2026 'da 8 milyar dolardan daha fazla 
olmasının beklendiği belirtilmiştir. Bununla beraber Kuzey Amerika dünya genelinde en geniş pazar payına sahipken, Asya Pasifik son yıllarda gösterdiği performansla Latin Amerika, Avrupa, Orta Doğu ve Afrika'yı geride birakarak en hızlı büyüyen pazar olmuştur. İnsanları doğrudan ya da dolaylı yollarla etkileyen mevcut ya da geliştirilmekte olan birçok IoNT uygulaması olsa da IoNT'nin insan yaşamına sağlayacağ faydalar henüz tam olarak kavranamamıştır.

\section{Uygulama Alanları}

Nano-aygıtların ortak bir amaç doğrultusunda bir araya gelerek oluşturdukları nano-ağ yapıları sağlık sektöründen askeri faaliyetlere kadar birçok farklı alanda sunduğu ve vadettiği yeniklerin bir sonucu olarak bugünlerde bir nano-üretim devrimi olarak kabul edilmektedir. $\mathrm{Bu}$ yenilikler, nano-aygıtların haberleşme türüne ve haberleşmenin gerçekleştiği ortama bağlı olarak farklı şekillerde isimlendirilmektedir. Bunlardan bazıları Kablosuz Nano-Duyarga Ağları, Vücut Nano-Duyarga Ağları, Vücut Alan Ağları, Kablosuz Vücut Alan Ağları, Biyo NanoNesnelerin İnterneti ve Multimedya Nano-Neslerin İnterneti'dir. Dahası gelecekte bu ve bunun gibi kavramların bir araya gelerek Her şeyin İnterneti - Internet of Everything (IoE)'ni oluşturacağ1 düşünülmektedir. Nano-aygıtlar farklı alanlarda potansiyel birçok uygulama vadediyor olsa da bu uygulamalar konularına ve kullanılan nano-aygıtların tiplerine bağlı olarak bazı gruplara ayrılmaktadır. Şekil 1'de mevcut ve potansiyel nano-ağ uygulamaları için örnek bir gruplandırma verilmiştir. Devam eden bölümde ise her bir uygulama alanı detaylı bir şekilde ele alınmıştır.
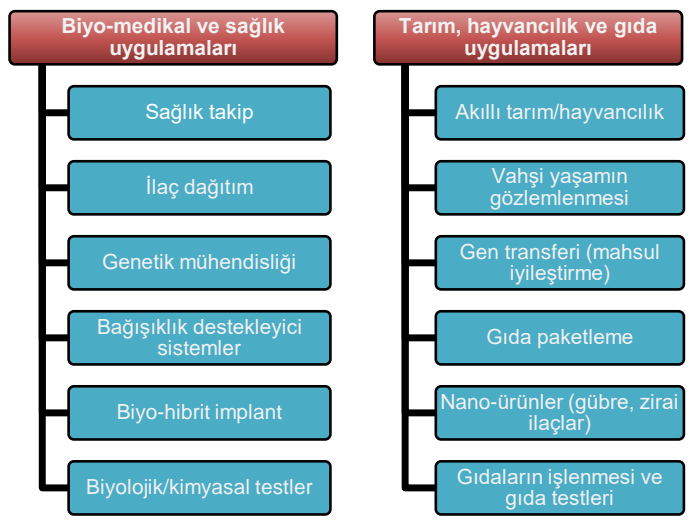
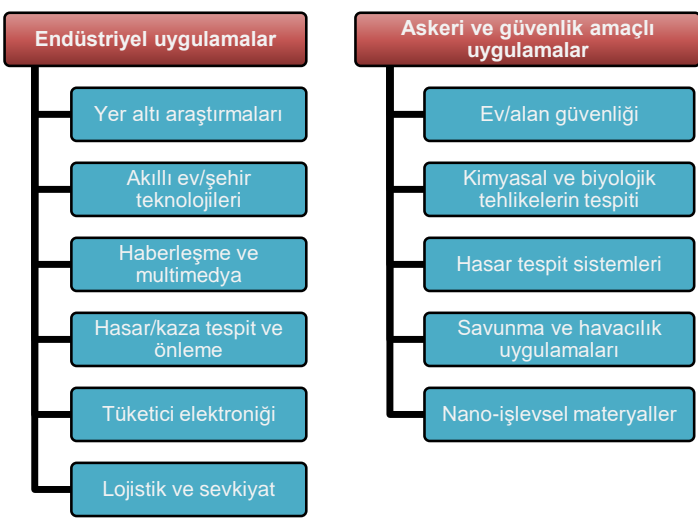

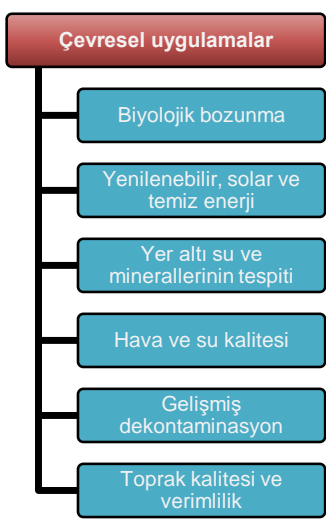

\section{Şekil 1: IoNT Uygulama Alanları}

\subsection{Biyo-medikal ve Sağlık Uygulamaları}

Nano-aygitlar, sahip olduğu biyo-uyumluluk ve küçük boyut gibi özellikleri sayesinde ilaç dağıtım, sağlık takip, biyo-hibrit implant, bağışıklık destek sistemleri ve genetik mühendisliği başta olmak üzere bu alana özgü devrim niteliğinde birçok uygulama vadetmektedir. Yapılan araştırmalar bu alandaki çalışmaların genellikle sağlık takibi üzerine yoğunlaştığını göstermektedir. $\mathrm{Bu}$ uygulamalar, vücut içerisine yerleştirilen nano-aygitlar vasitasıyla insanların vücut sıcaklığı, oksijen ve kolesterol seviyesi gibi hayati bilgilerinin gözlemlenerek herhangi bir sebepten dolayı meydana gelebilecek hormonsal ve kimyasal bozulmaların anlık olarak tespit edilebilmesini amaçlamaktadır (Balasubramaniam ve Kangasharju, 2012; Jarmakiewicz ve ark., 2016). Şekil 2 (a)'da basit bir sağlık takip uygulaması örneği verilmiştir. Bu uygulamada, en basit nanoaygıt olan nano-duyargalar, bulundukları bölgeye ait sağlık verilerini oluşturmaktan ve bunları nano-duyargalara göre kısmen daha gelişmiş olan nano-yönlendiricilere aktarmaktan sorumludur. Nano-yönlendiriciler ise topladıkları verileri bir nano-arayüze aktararak verilerin geleneksel internet uygulamaları tarafından erişilebilir olmasını sağlar. Bu sayede de hasta ya da sağlıklı bireylerin hayati değerleri hem sağlık merkezleri hem de sağlık çalışanları tarafından anlık olarak gözlemlenebilir. Burada, nano-arayüz olarak adlandırılan yapıların hem nano hem de geleneksel ağ teknolojileri ile haberleşmeyi sağlayan gelişmiş bir nano-aygıt olduğu da unutulmamalıdır. Bu uygulamaların son yıllardaki giderek artan popülerliklerinin en önemli sebeplerinden biri de bu tip uygulamaların insan yaşam kalitesini arttırıyor olmasıdır. Özellikle tespit edilmesi ya da tanı konulması için oldukça yoğun süreçleri gerektiren kanser hücresi veya patolojik yapıların tespiti nano-aygıtlardan oluşan nano-ağ yapıları sayesinde daha kısa sürede ve daha az maliyetle yapılabilir. Ayrıca bu tip hastalıklarda tedavi başarımını arttıran en büyük etken erken tanıdır. Bu bağlamda vücut içerisinde bulunan nanoaygitlar sayesinde bu tip hastalıkların ya da rahatsızlıkların ortaya çıkar çıkmaz tespit edilmesi sağlanabilir.

Nano-aygıtların yaygın olarak kullanıldığı uygulamalardan bir diğeri de ilaç dağıtım sistemleridir. $\mathrm{Bu}$ sistemlerde amaç önceden tespit edilen bir hastalık ya da anormal bir durum için uygun tedavinin nano-aygitlar vasıtasıyla doğrudan ilgili bölgeye uygulanmasıdır. $\mathrm{Bu}$ durum tedavinin doğrudan ilgili bölgeye uygulanmasından dolayı başarımın artması ve tedavi yöntemlerindeki yan etkilerin azalması gibi avantajları da beraberinde getirmektedir. Özellikle kanser ve böbrek yetmezliği gibi tedavi süreci ve yan etkileri ağır olan hastalıklar dikkate alındığında bu yapıların oldukça kullanışlı olacağı düşünülmektedir. Dahası bu teknolojik gelişmelerin ilaç sektöründe köklü değişikliklere neden olacağı da bir gerçektir.

Mayıs 2021 tarihi itibariyle halen tüm dünyada etkisini sürdüren Covid-19 yakın geçmişteki en büyük salgın olarak kabul edilmektedir. Dünya genelinde 3 milyondan fazla insanın hayatını kaybetmesine neden olan bu salgın ekonomik, sosyal ve kültürel bakımdan da tüm dünyayı olumsuz yönde etkilemektedir. Dahası bu gibi salgınlarda, salgının kontrol altına alınamamasının en önemli sebeplerinden birisi de virüse maruz kalan kişilerin test yaptırmaktan kaçınması sonucunda olası hastaların tespit edilememesidir. Nano-ăg uygulamaları sayesinde (özellikle vücut içi) kişilerin kendi tercihine bakılmaksızın otonom olarak yapılacak testlerden elde edilen sonuçlar ilgili kurumlara aktarılarak tüm hastaların ve temaslı olduğu kişilerin doğru ve eksiksiz bir biçimde tespit edilerek, en kısa sürede gözetim altına alınması sağlanabilir. 
İnsan ya da hayvan yaşamını olumsuz yönde etkileyen en önemli şeylerden birisi de doğuştan ya da bir kaza sonucu meydana gelen organ kayıplarıdır. Bu bağlamda nano-aygıtlar, zarar görmüş doku ve organları destekleyecek ya da tamamen yerini alacak biyo-hibrit tedavi yöntemleri ve implant teknolojileri geliştirmek amacıyla da kullanılabilir. Dahası bu nano-aygıtların bir araya gelmesiyle zarar görmüş merkezi sinir sisteminin kismen ya da tamamen yerini alabilecek yapay bir sistem geliştirilerek bunama ve Alzheimer gibi hastalıkların tedavisi de gerçekleştirilebilir. Tüm bunların yanı sıra nanoaygitlar, DNA teşhisinden, moleküler dizilim ve modifikasyona kadar birçok farklı genetik mühendisliği çalışması için de potansiyel uygulamalara gebedir.

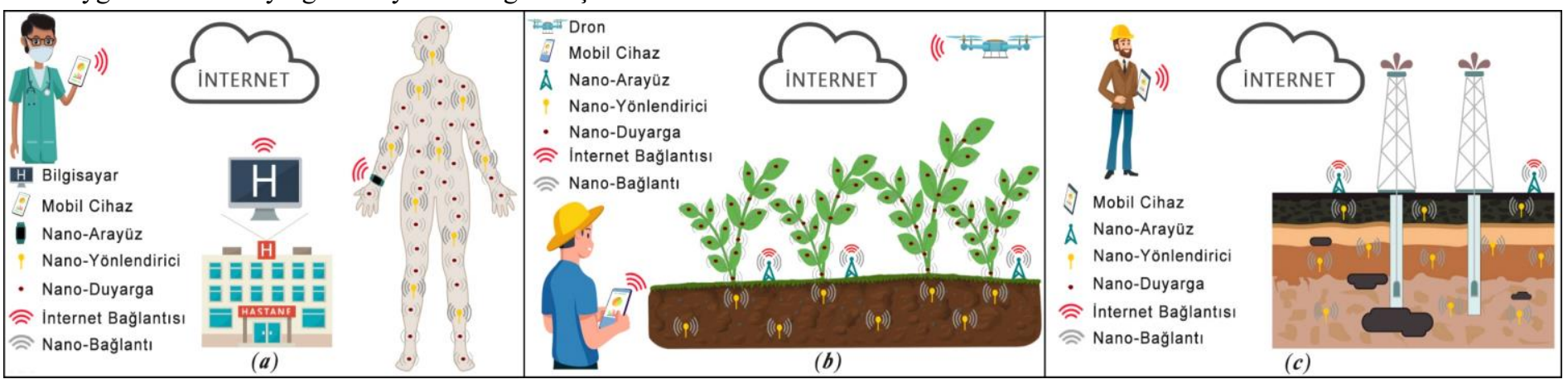

Şekil 2: IoNT Uygulamaları a) Sağllk Takip Uygulaması b) Akallı Tarım Uygulaması c) Endüstriyel Nano-Ağ Uygulaması

\subsection{Tarım, Hayvancılık ve GıdaUygulamaları}

Günümüzde giderek azalan tarım ve hayvancilık alanlarından en yüksek verimi alabilmek amacıyla son yıllarda akıllı tarım ve akıllı üretim kavramları oldukça popüler bir hale gelmiştir. Bu doğrultuda nano-ağ uygulamalarının da potansiyel birçok çözüm sunacağı düşünülmektedir. Bu çözümler arasında hayvanların etkin bir şekilde beslenmesi, zirai ilaçların uygun bir şekilde kullanılması, tarım alanlarına ait bilgilerin toplanması, toprağa, bitkiye, hayvanlara ya da diğer ortamlara yerleştirilecek nano-aygttlar sayesinde hayvanların/bitkilerin sağlık verilerinin izlenmesi gibi uygulamalar yer almaktadır. Bu uygulamalar sayesinde hayvan ve bitkilerin sağlık durumları gerçek zamanlı olarak takip edilerek hastalıkların ya da diğer olumsuz durumların kısa sürede tespit edilmesi sağlanabilir (Meena ve ark., 2018). Dahası bu nano-aygıtlar, enzimlerin ve ilaçların salınımını tetikleyerek doğrudan tedavi sürecine de dahil olabilirler. Geçmişte binlerce hayvanın ve bitkinin telef olmasına neden olan salgın hastalıklar dikkate alındığında bu tür uygulamaların hastalıkların tespit edilmesi ve önlenmesi açısından oldukça önemli olduğu düşünülmektedir. Nano-ă̆ teknolojilerinin tarım alanlarındaki kullanımına ilişkin bir örnek Şekil 2 (b)'de gösterilmiştir. Bu uygulamada, toprağa ve bitkilere yerleștirilen nano-aygıtlar vasıtasıyla elde edilen bilgilerin (toprağa ait nemlilik, mineral miktarı ve bitkinin sağllk verileri), bir mobil cihaz üzerinden anlık olarak takip edilebilmesi amaçlanmaktadır. Ayrıca bu yapıya mevcut dron ve robot teknolojilerinin entegrasyonuyla ilgili bölgedeki güvenlik, gözetim ve tarım faaliyetlerinin otonom bir şekilde sürdürülmesi de sağlanabilir. Diğer yandan nano-aygttlar küçük boyutları nedeniyle canlıların yaşamlarını kısıtlamayacağı için yaban hayatın gözlenmesi ve araştırılmasına yönelik çalışmalar için de oldukça uygundur.

Tarımsal faaliyetlerde en önemli gider kalemini zirai ilaçlar ve gübreler oluşturmaktadır. Ayrıca her yıl dünya genelinde 26 milyon insan bu ilaçlar nedeniyle zehirlenirken, 220 bin insansa hayatını kaybetmektedir (Maksimović ve ark., 2019). Bu doğrultuda, nano-aygıtlar, toprakla ilgili gerçek zamanlı bilgilerden yararlanılarak kontrollü/etkin gübreleme ve ilaçlama yapmak için kullanılabilirler. Diğer yandan dünya üzerindeki su kaynakları her geçen gün giderek azalmaktadır ve bunun en büyük nedenlerinden birisi de tarımdaki bilinçsiz sulama faaliyetleridir. Bu noktada, bitkilere ya da toprağa yerleştirilen e-ISSN: $2148-2683$ nano-aygitlar etkin sulama faaliyetleri amaciyla da kullanılabilirler (Antonacci ve ark., 2018). Ayrıca bu yapılardan yararlanılarak toprak özelliklerine bağlı karar destek sistemleri de oluşturulabilir. Dahası bu nano-aygıtlar vasıtasıyla bitkiler arasındaki polen aktarım sürecini kolaylaştıracak yapay aşılama ve döllenme sistemleri geliştirilebilir. Benzer şekilde nanoaygitlar tarafindan salgilanan enzim ve kimyasallar vasitasıla hayvanların hormonsal yapılarına müdahale edilerek üreme gibi faaliyetleri kontrol altına alınabilir.

Nano-aygıtların etkin bir şekilde kullanılabileceği alanlardan bir diğeri de gidaların üretim ve paketlenme sürecindeki faaliyetlerdir. Bu kapsamda nano-aygitlar vasitasıyla, hayvanlar için tükettiği yemlerin, bitkiler içinse kullanılan zirai ilaç ve gübrelerin gözlemlenmesi sonucu elde edilen bilgilerden yararlanılarak gıdaların kalite ve besin değeri açısından derecelendirilmesine yönelik çalışmalar yapılabilir. Türüne göre değişmekle birlikte tüm gıda ürünlerinin toplandıktan ya da paketlendikten sonra belli bir süre içerisinde tüketilmesi gerekir. Fakat bu süre ideal koşullar göz önünde bulundurularak belirlenir, ama bazen gerek sevkiyat gerekse depolama süreçlerinde gıdalar uygun olmayan koşullara maruz kalabilmekte, bu durum da gıdaların tazeliğini ve kalitesini doğrudan etkilemektedir. Bu doğrultuda, gıda ambalajlarının üzerine yerleştirilen nano-aygıtlardan yararlanılarak gıdaların tazeliğini anlık olarak ölçebilecek gerçek zamanlı sistemler tasarlanabilir. Diğer yandan, nano-aygitlar bitkilerin ya da hayvanların bazı genetik özelliklerini değiştirerek çevre koşullarına, hastalıklara ve bakterilere karşı daha dayanıklı türlerin geliştirilmesi amacıyla da kullanılabilirler.

\subsection{Endüstriyel Uygulamalar}

Endüstriyel nano-ağ uygulamaları kalite kontrol, ürün geliştirme ve üretim süreçlerinin izlenmesi amacıyla nanoaygıtların bir araya getirildiği sistemleri içermektedir. Bu alanda, nano-aygitların genellikle leke tutmayan ve antimikrobiyal kumaş gibi fonksiyonel malzemelerin üretimi için kullanılması amaçlanmaktadır. Dahası kumaş üzerine yerleştirilen bu nanoaygıtlar dış koşullara bağlı olarak kumaş üzerindeki hava akışını düzenlemek için de kullanılabilirler. Geliştirilen bu işlevsel materyaller birçok farklı faaliyet kolunda üretilen ürünlerin konfor seviyesini önemli düzeyde yükseltecek yenilikler içermektedir. Diğer taraftan bu materyallerin özellikle inşaat ve 
otomotiv sektöründeki ürünlere kaza/hasar algılama ve önleme gibi özellikler kazandırması da beklenmektedir. $\mathrm{Bu}$ bağlamda araç içerisindeki nano-aygıtlar vasıtasıyla sürücülerin yorgunluk, alkol, uyuşturucu ve diğer sağlık bilgileri anlık olarak tespit edilerek olası felaketleri önlemeye yönelik tedbirler alınabilir. Benzer şekilde tuğlaların içerisine yerleştirilecek nano-aygıtlar, yapıların dayanıklılığını anlık olarak ölçmeyi ve olası bir olumsuz durumda mikro ve makro ölçekteki aygıtlarla iletişime geçerek insanların zamanında uyarılmasını sağlayabilirler. Bu durum, günümüzde oldukça popüler uygulamalardan birisi olan akıllı ev teknolojilerine de farklı bir boyut kazandırabilir. Dahası bu sistem, deprem vb. nedenlerden dolayı meydana gelen yıkılmalarda nano-aygıtların enkaz alanına saçılması sonucunda enkaz bölgesi hakkında bilgi toplamak için de kullanılabilir.

Nano-aygıtlar, küçük boyutları sayesinde yeraltındaki petrol/gaz miktarının ve konumunun net olarak belirlenmesine yönelik çalışmalarda da kullanılabilirler. Şekil 2 (c)'de zemindeki çeşitli çatlaklardan ve boşluklardan içeriye doğru gönderilen nano-aygıtların yeraltındaki petrol kaynaklarına ait konum, kalite ve miktar gibi bilgilerinin daha az iş gücü ve maliyetle elde edilmesine yönelik bir örnek verilmiştir. Benzer şekilde, olası bir kaza durumunda yüzlerce insanın hayatını kaybetmesine neden olan madencilik ve mermer çıkarma faaliyetleri de nano-ağ uygulamalarının potansiyel uygulama alanları arasındadır. Dahası günümüzde en hızlı tükenen kaynaklarımızdan birisi olan su için alternatif yer altı kaynaklarının tespit edilmesi çalışmalarında da nano-aygıtlardan yararlanılabileceği düşünülmektedir.

Elektromanyetik haberleşmenin kullanıldı̆̆ uygulamaları $\mathrm{THz}$ frekansının sahip olduğu geniş bant aralığı sayesinde multimedya uygulamaları için devrim niteliğinde yenilikler vadetmektedir. Bunların başında da saniyede terabitlik veri aktarımına olanak sağlaması gelmektedir. Ayrıca bu alandaki yenilikler sonucunda geliştirilen ultra yüksek çözünürlüklü görüntüleme yapmaya olanak sağlayan minyatür fotosel ve nano boyutlardaki akustik dönüştürücüler yakın gelecekte iletişim, haberleşme ve multimedya alanındaki uygulamaları kökünden değiştirecektir (Acharjya ve ark., 2017). Diğer yandan her geçen gün internete bağlanan cihaz sayısının giderek arttığı göz önünde bulundurulduğunda yakın gelecekte mevcut haberleşme alt yapılarının yetersiz kalacağı bir gerçektir. $\mathrm{Bu}$ noktada $\mathrm{THz}$ frekansının, sahip olduğu yüksek veri aktarım kapasitesi sayesinde $6 \mathrm{G}$ teknolojisinin alt yapısını oluşturacağı düşünülmektedir. Ayrıca havada ya da herhangi bir yüzey üzerinde yayılan nano-aygitlar sayesinde ultra hassas algilama ve dokunma teknolojileri de geliştirilebilir. Tüm bunların sağlık sektöründen eğlence sektörüne kadar birçok alanı derinden etkilemesi beklenmektedir. Özellikle uzaktan ya da sanal eğitim ve iş süreçleri için sanal/artırılmış gerçeklik ve hologram teknolojileri ile birleştirilecek hibrit IoNT uygulamaları pratik gerektiren eğitim ve iş süreçleri için bambaşka bir deneyim sunacaktır.

\subsection{Askeri ve Güvenlik Amaçlı Uygulamalar}

Günümüzde birçok ülkenin biyolojik ve kimyasal silahlar geliştirdiği bilinmektedir. Olası bir savaş durumunda bu silahların kullanılması geri döndürülemez sonuçlar doğurabilir. Bu noktada, nano-aygıtlar belli bir bölgedeki zararlı biyolojik ve kimyasal bileşenlerin tespit edilmesi için kullanılabilirler. $\mathrm{Bu}$ bileşenlerin tespiti amacıyla kullanılan oldukça gelişmiş cihazlar mevcut olsa da nano-aygıtların en büyük avantajı bu tip yapı ve bileşenlerin varlığını atomik ve moleküler düzeyde bile tespit edebiliyor olmalarıdır. Benzer şekilde, nano-aygıtlar herhangi bir gözetleme veya radar sistemi tarafindan tespit edilmeden, savaş alanlarında bilgi toplamak için de oldukça uygundurlar (Akyildiz ve ark., 2008). Şekil 3 (a)'da örnek bir uygulama verilmiştir. Burada amaç, nano-aygıtlar tarafindan izinsiz bir girişimin tespit edilmesi durumunda kendisine en yakın erişim noktası (EN) üzerinden kontrol merkezinin uyarılarak insansız hava araçları tarafından gerekli yaptırımların uygulanmasını sağlamaktır. $\mathrm{Bu}$ sayede yasaklı bölgelerdeki denetim ve güvenlik sistemleri yarı ya da tamamen otonom hale getirilebilir. Dahası nano-aygitlar toprak altındaki ya da üzerindeki çeşitli patlayıcıların tespit ve imha edilmesi çalışmalarında da kullanılabilirler.

Nanoteknoloji devrimi, tıpkı diğer alanlarda olduğu gibi askeri donanım ve ekipmanları da etkilemektedir. $\mathrm{Bu}$ gelişmelerin bir sonucu olarak nano-aygıtların su geçirmeyen, renk değiştiren ve askerlerin hayati değerlerinin anlık olarak gözlemlenmesini sağlayan kamuflaj/üniformalardan, kendi kendini onaran çadır ve tuluma kadar farklı birçok ekipmanın geliştirilmesinde kullanılabileceği düşünülmektedir (Jarmakiewicz ve ark., 2016). Diğer yandan nano-aygitlar askeri ekipmanlardaki, mevcut radar sistemleriyle tespit edilemeyen hasarların tespit edilmesi için de kullanılabilir (Acharjya ve ark., 2017).

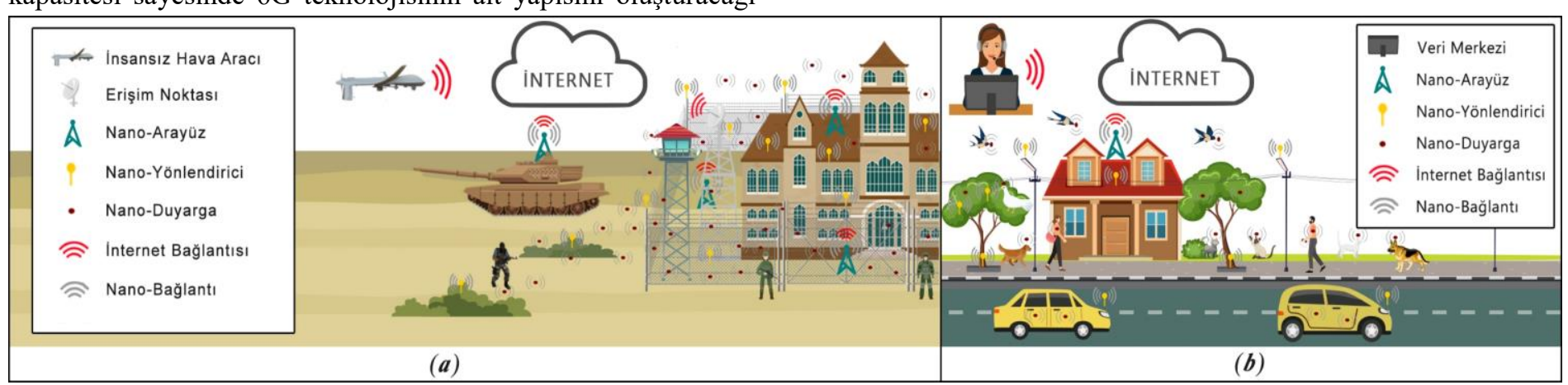

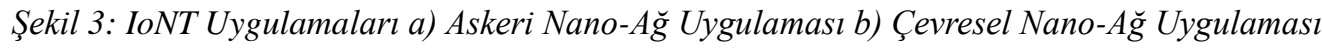

\section{5.Çevresel Uygulamalar}

İnsan yaşamını olumsuz yönde etkileyen faktörlerin başında çevre ve hava kirliliği gelmektedir. Çevre ve hava koşullarındaki bu olumsuz durumlar iklim değişiklerine ve ekosistem bozukluklarına neden olmaktadır. Bu doğrultuda nano-aygıtlar çevre ve hava kalitesini anlık olarak ölçmek amacıyla kullanılabilirler (Rafae ve ark., 2019). Şekil 3 (b)'de hava kirliliğinin tespit edilmesine yönelik örnek bir uygulama verilmiştir. Burada, bitki, hayvan ve araçlar üzerindeki nanoduyargalar tarafından elde edilen değerler, ortamdaki herhangi bir nesne üzerinde bulunan nano-yönlendiriciler tarafindan 
toplanarak, en yakın nano-arayüz üzerinden veri merkezlerine aktarılır. Dahası bu yapı sayesinde ortam şartları kabul edilebilir asgari şartlardan daha kötü bir duruma geldiğinde merkezi kontrol sistemi uyarılarak gerekli tedbirlerin alınması sağlanabilir.

İklim değişikliğinin ve ekosistem bozukluklarının en önemli nedenlerinden birisi de geleneksel tarım faaliyetlerindeki gibi bilinçsiz gübreleme ve tarım ilacı kullanımıdır (Maksimović ve ark., 2019). Buna göre nano-ağ uygulamaları vasitasıyla gübre, tarım ilacı ve suyun bilinçli kullanımı çevre ve hava kirliliğini de azaltacaktır. Dahası çevre ve hava kalitesini arttırmak için havanın içerisinde bulunan zararlı bileşenleri ortadan kaldırabilecek çeşitli nano-ağ uygulamaları da geliştirilebilir. Diğer yandan yoğunluğun çok fazla olduğu lokasyonlara yerleştirilecek nano-aygitlarla ortamın kalitesine ait veriler anlık olarak toplanabilir, toplanan bu veriler de kalabalık ortamlardaki viral virüslerin varlığını ve nasıl yayıldığını tespit etmek için kullanılabilirler.

Günümüzde hava kirliliği, ekosistemdeki bozulmalar ve doğal yaşam alanlarının tahribatı gibi nedenlerden dolayı birçok canlının nesli tükenme tehlikesi altındadır. Bu bağlamda nano-ağ yapıları, canlıların üreme ve çeşitliliğini kontrol altında tutmak amacıyla da kullanılabilirler. Örneğin çoğu hayvanın kendi aralarında haberleşmek için kullandıkları feromonlar nanoaygıtlar tarafından denetlenerek, ilgili canlının davranışları kontrol altına alınabilir. Ayrıca nano-aygıtlar çöp arıtma ve geri dönüşüm süreçlerinde biyo-bozunmayı destekleyici ya da hızlandırıcı yapılar olarak da kullanılabilir.

\section{Sonuç}

Nano-ağ uygulamalarında genellikle elektromanyetik ve moleküler olmak üzere iki farklı haberleşme tipi kullanılmaktadır. Moleküler haberleşme biyo-uyumluluk ve özellikle vücut içi ortamlardaki uygulanabilirliği nedeniyle elektromanyetik haberleşmeye göre daha avantajlı olsa da bilginin özel moleküller üzerine kodlanarak gönderildiği bu haberleşme tipinde alıcı ve gönderici taraftaki bu kodlama, kod çözme işlemlerinin nasıl yapılacağı ve bu özel moleküllerin yoğunluğunun neye göre belirleneceği halen araştırılan konulardır. Dahası kullanılan bu özel moleküllerin ortamdaki organ ya da biyolojik yapıları etkileyip etkilemeyeceği de başka bir araştırma konusudur. Elektromanyetik haberleşmenin kullanıldığı nano-ağ uygulamalarında ise ortamdaki moleküllerin titreşmesine bağlı olarak yol kaybının yüksek olmasından dolayı nano-aygıtların iletim mesafesi oldukça sınırlıdır. Dahası elektromanyetik haberleşmede ortamdaki moleküllerin titreşmesi sonucu ortaya çıkan kinetik enerji ortamdaki isının artmasına neden olmaktadır. Yapılan çalışmalar termal gürültü olarak adlandırılan bu durumun tehlikeli boyutlara ulaşacak kadar yüksek olmadığını gösterse de bu durumun vücut içi uygulamalar için tehdit oluşturup oluşturmayacağı halen araştırılan konular arasındadır. Diğer yandan nano-ă̆ uygulamaları seçilen haberleşme tipine bağlı olarak yeni kanal modellerine ve anten teknolojilerine de gereksinim duymaktadırlar. Ayrıca binlerce nano-aygittan meydana gelen bu ağ yapısında, çakışmaların önlenmesi adına yeni kanal erişim mekanizmalarına, bilginin bir noktadan başka bir noktaya başarılı bir ş̧ekilde aktarılması içinse yeni yönlendirme protokollerine ihtiyaç vardır.

Her ne kadar günümüzde nano-ağ teknolojileri hali hazırda çözülmesi gereken önemli problemlere sahip olsa da sunduğu ve e-ISSN : 2148-2683 vadettiği uygulamalar dikkate alındığında bir teknoloji devrimi olarak kabul görmektedir. Dahası bu kavramın geleceğin internet ve haberleşme teknolojilerinin de alt yapısını oluşturacağ düşünülmektedir. Sonuç olarak nanoteknolojinin mevcut ve potansiyel uygulamaları düşünüldüğünde IoNT'nin kısa bir süre içerisinde hayatımızın hemen hemen her noktasında karşımıza çıkacağı bir gerçektir. Bu bağlamda da gelecek birkaç yıl içerisinde mevcut problemlerin çözümüne yönelik gerek akademik gerekse ticari çalışmaların hız kazanması beklenmektedir.

\section{Kaynakça}

Acharjya, D. P., Geetha, M. K., \& Sanyal, S. (Eds.). (2017). Internet of things: novel advances and envisioned applications. Springer International Publishing.

Akyildiz, I. F., Brunetti, F., \& Blázquez, C. (2008). Nanonetworks: A new communication paradigm. Computer Networks, 52(12), 2260-2279.

Akyildiz, I. F., \& Jornet, J. M. (2010). The internet of nanothings. IEEE Wireless Communications, 17(6), 58-63.

Antonacci, A., Arduini, F., Moscone, D., Palleschi, G., \& Scognamiglio, V. (2018). Nanostructured (bio) sensors for smart agriculture. TrAC Trends in Analytical Chemistry, 98, 95-103.

Balasubramaniam, S., \& Kangasharju, J. (2012). Realizing the internet of nano things: challenges, solutions, and applications. Computer, 46(2), 62-68.

Jarmakiewicz, J., Parobczak, K., \& Maślanka, K. (2016). On the internet of nano things in healthcare network. Proceedings of the 2016 International Conference on Military Communications and Information Systems (ICMCIS), (1-6).

Maksimović, M., Omanović-Mikličanin, E., \& Badnjević, A. (2019). Nanofood and internet of nano things. Springer International Publishing.

Meena, N., Sahni, Y., Thakur, D., \& Singh, R. (2018). Applications of nanotechnology in veterinary therapeutics. Journal of Entomology and Zoology Studies, 6(2), 167-175.

Rafae, H., Jamil, S. W., Aslam, M. I., \& Ahmed, I. (2019). Internet of nano things: next step for future of nanotechnology. Proceedings of the 4th International Electrical Engineering Conference (IEEC), (1-8). 